\title{
AKTIVITAS ANTI-HIPERGLIKEMIA EKSTRAK ETANOL Turbinaria decurrens
}

\author{
Thamrin Wikanta"), Dian Kristi*), Lestari Rahayu**), dan Nurrahmi Dewi Fajarningsih")
} \begin{abstract}
ABSTRAK
Telah dilakukan penelitian tentang pengaruh pemberian ekstrak etanol Turbinaria decurrens terhadap penurunan kadar glukosa darah tikus hiperglikemik. Dibuat 6 kelompok perlakuan hewan percobaan, masing-masing kelompok terdiri dari 5 ekor. Hewan percobaan (kecuali kontrol normal) dibuat hiperglikemik dengan suntikan aloksan tetrahidrat secara intravena pada dosis $130 \mathrm{mg} / \mathrm{kg} \mathrm{BB}$. Kelompok I (kontrol normal) tidak diberi perlakuan; kelompok II (kontrol negatif) diberikan perlakuan air suling; kelompok III diberikan ekstrak T. decurrens dosis rendah 0,85 $\mathrm{g} / \mathrm{kg}$ $\mathrm{BB}$; kelompok IV diberikan ekstrak $T$. decurrens dosis sedang $1,70 \mathrm{~g} / \mathrm{kg} \mathrm{BB}$; kelompok $\mathrm{V}$ diberikan ekstrak $T$. decurrens dosis tinggi $3,40 \mathrm{~g} / \mathrm{kg} \mathrm{BB}$; kelompok VI kontrol positif diberikan glibenklamid $0,90 \mathrm{mg} / \mathrm{kg}$ BB. Ekstrak $T$. decurrens dan obat glibenklamid diberikan secara oral selama 20 hari. Pada hari ke- $0,5,10,15$, dan 20 sejak kondisi awal hiperglikemik, semua hewan percobaan diambil sampel darahnya, dan diukur kadar glukosa darahnya. Di akhir masa percobaan, semua tikus dibedah dan diambil organ pankreasnya untuk dilakukan pengamatan histopatologi. Hasil penelitian menunjukkan bahwa pemberian ekstrak etanol $T$. decurrens pada dosis $0,85 \mathrm{~g} / \mathrm{kg} \mathrm{BB}$, dosis $1,70 \mathrm{~g} / \mathrm{kg} \mathrm{BB}$, dan dosis $3,40 \mathrm{~g} / \mathrm{kg}$ BB dapat menurunkan kadar glukosa darah tikus yang mengalami kondisi hiperglikemik. Ekstrak etanol $T$. decurrens dosis $3,40 \mathrm{~g} / \mathrm{kg}$ BB mempunyai potensi yang lebih baik dibandingkan glibenklamid dosis $0,90 \mathrm{mg} / \mathrm{kg}$ BB sebagai kontrol positif dalam menurunkan kadar glukosa darah tikus. Analisis histopatologi menunjukkan bahwa ekstrak etanol T. decurrens dapat membantu pemulihan kondisi hiperglikemia tikus yang ditandai dengan peningkatan nilai rata-rata diameter pulau Langerhans dan jumlah sel- $\beta$ pankreas di dalam pulau Langerhans hingga kembali mendekati kondisi normal.
\end{abstract}

KATA KUNCl: $\quad$ hiperglikemia, Turbinaria decurrens, kadar glukosa darah, sel- $\beta$ pankreas

ABSTRACT: Antihyperglycemic activity of Turbinaria decurrens ethanol extract. By: Thamrin Wikanta, Dian Kristi, Lestari Rahayu and Nurrahmi Dewi Fajarningsih

Research on the effect of Turbinaria decurrens ethanol extract feeding on the reduction of high blood glucose level (hyperglycemia) rat has been carried out. Six groups of treatments were made, each group consisted of 5 rats. The rats (except for normal control) were induced into hyperglycemic condition by intravenally injection of alloxan tetrahydrate at the dose of $130 \mathrm{mg} / \mathrm{kg}$ $B W$. Group I was untreated (normal control), group II was treated with distilled water (negative control), group III was treated with T. decurrens ethanol extract at low dose $(0,85 \mathrm{~g} / \mathrm{kg} B W) ;$ group IV was treated with $T$. decurrens ethanol extract at medium dose $(1.70 \mathrm{~g} / \mathrm{kg} \mathrm{BW}) ;$ group $V$ was treated with $T$. decurrens ethanol extract at high dose $(3.40 \mathrm{~g} / \mathrm{kg} \mathrm{BW}) ;$ group VI (positive control) was treated with glibenclamid at the dose of $0.90 \mathrm{mg} / \mathrm{kg} \mathrm{BW}$. T. decurrens extract and glibenclamid treatment were given orally for 20 days. Blood samples were collected from each rat at day 0,5 , 10, 15 and 20 since hyperglychemic condition achieved, and blood glucose level was measured. At the end of the experiment, all rats were, dissected and pancreas organs were taken for histopathological observation. The research revealed that feeding hyperglychemic rats with $T$. decurrens ethanol extract at the dose of $0.85 \mathrm{~g} / \mathrm{kg} \mathrm{BW,} 1.70 \mathrm{~g} / \mathrm{kg} \mathrm{BW}$ and $3.40 \mathrm{~g} / \mathrm{kg} \mathrm{BW}$ were ab/e to reduce the blood glucose level of hyperglycemic rats. The treatment of $T$. decurrens ethanol extract at the dose of $3.40 \mathrm{~g} / \mathrm{kg} \mathrm{BW}$ showed better potency than the treatment of glibenclamid at the dose of $0.90 \mathrm{mg} / \mathrm{kg} \mathrm{BW}$ in reducing the blood glucose level of hyperglycemic rats. Histopathological analysis revealed that $\mathrm{T}$. decurrens ethanol extract was able to support the recovery of hyperglycemic rats by increasing the diameter size of Langerhans islet and by increasing the number of pancreatic $\beta$-cell in the Langerhans islet toward normal condition.

KEYWORDS: $\quad$ hyperglycemic, Turbinaria decurrens, blood glucose level, pancreatic $\beta$-cell

Peneliti pada Balai Besar Penelitian dan Pengembangan Pengolahan Produk dan Bioteknologi Kelautan dan Perikanan, Balitbang KP, KKP; JI. KS. Tubun Petamburan VI, Jakarta Pusat; E-mail: thamrin_wikanta@yahoo.com

Fakultas Farmasi - Universitas Pancasila; Srengseng Sawah, Jagakarsa, Jakarta Selatan 


\section{PENDAHULUAN}

Terjadinya pergeseran pola makan di masyarakat dewasa ini, dari pola makanan tradisional yang kaya serat ke makanan cepat saji yang kaya akan lemak dan protein, atau makanan-makanan berpengawet dengan daya simpan lama menimbulkan terjadinya berbagai macam penyakit, salah satu di antaranya adalah diabetes mellitus (DM). Jenis penyakit DM ditandai dengan kadar glukosa darah yang melebihi normal atau disebut hiperglikemia. Kondisi hiperglikemia tersebut salah satunya disebabkan oleh kerusakan sel beta pankreas yang berakibat pada ketidakmampuan pankreas untuk memproduksi insulin yang dibutuhkan untuk mengubah glukosa menjadi energi (Tjokroprawiro, 1999; Dalimartha, 2002). Selain karena proses degeneratif, kerusakan pankreas juga dapat disebabkan oleh konsumsi makanan yang menghasilkan radikal bebas di dalam tubuh. Radikal bebas dapat memicu terjadinya kerusakan berbagai jaringan organ tubuh, di antaranya organ pankreas (Halliwell, 1999; Halliwell et al., 1999).

Antioksidan mempunyai banyak fungsi penting untuk menjaga kesehatan. Antioksidan alami telah dilaporkan mampu mengurangi resiko penyakit kanker, penyakit kardiovaskular, dan berbagai penyakit akibat penuaan. Telah dilaporkan pula bahwa aktivitas antidiabetes berbagai senyawa bahan alam dari tanaman berkaitan dengan aktivitas antioksidan yang dikandungnya (Djilani et al., 2011). Konsumsi makanan yang mengandung senyawa antioksidan diketahui dapat mereduksi efek negatif radikal bebas sehingga mampu mencegah atau mengurangi komplikasi diabetes.

Masyarakat Jepang adalah konsumen rumput laut terbesar di dunia sehingga mereka memiliki kecenderungan terkecil di dunia dalam menderita penyakit berat seperti kanker dan penyakit degeneratif lainnya. Hal ini terjadi karena rumput laut mengandung zat antioksidan karoten, khlorofil, dan polifenol. Penelitian Wikanta et al. (2010) menunjukkan bahwa ekstrak etanol Turbinaria decurrens ( $T$. decurrens) mempunyai aktivitas sebagai antioksidan dan hepatoprotektor. Pelarut etanol biasa digunakan untuk memproduksi ekstrak herbal di bidang medis. Dalam kadar rendah, etanol bersifat aman untuk dikonsumsi sehingga sering digunakan sebagai pelarut obat yang sukar larut dalam air.

Berdasarkan sifat antioksidan rumput laut $T$. decurrens tersebut, maka dilakukan penelitian yang bertujuan untuk mengetahui pengaruh pemberian ekstrak etanol $T$. decurrens terhadap kadar glukosa darah tikus yang mengalami hiperglikemia akibat injeksi aloksan tetrahidrat. Pemeriksaan histopatologi juga dilakukan untuk mengetahui perubahan yang terjadi pada pankreas tikus hiperglikemia yang diberi perlakuan ekstrak etanol $T$. decurrens.

\section{BAHAN DAN METODE}

\section{Bahan Penelitian}

Bahan yang digunakan dalam penelitian ini adalah ekstrak etanol rumput laut Turbinaria decurrens hasil panen dari pantai Binuangeun, Banten Selatan. Seluruh bagian tanaman rumput laut $T$. decurrens yang telah dicuci dengan air bersih, ditiriskan, lalu dimaserasi dalam etanol 95\% selama 1 minggu, kemudian ekstrak disaring, dan dilakukan evaporasi untuk menghilangkan pelarut hingga didapatkan ekstrak kental. Selanjutnya ekstrak kental tersebut dikeringbekukan dengan freeze dryer (Labconco). Untuk mencegah kerusakan, ekstrak kering yang dihasilkan disimpan dalam inkubator suhu $10^{\circ} \mathrm{C}$.

\section{Hewan Percobaan}

Hewan percobaan yang digunakan pada penelitian ini adalah tikus putih (Rattus norvegicus L.) galur wistar, jenis kelamin jantan, bobot badan antara 150200 gram, berumur 3-3,5 bulan yang diperoleh dari Fakultas Kedokteran Hewan Institut Pertanian Bogor. Sebelum penelitian dilaksanakan, tikus dipelihara terlebih dahulu selama kurang lebih satu minggu untuk adaptasi lingkungan, mengontrol kesehatan, bobot badan, dan jumlah pakan (KKI Phytomedica, 1993).

\section{Metode}

\section{Pembuatan tikus hiperglikemik}

Aloksan memiliki sifat diabetogenik dan bersifat selektif merusak sel $\beta$-pankreas sehingga aloksan banyak digunakan untuk percobaan diabetes mellitus pada hewan percobaan (Szkudelski, 2001). Pemberian aloksan mengakibatkan terjadinya peroksidasi pada membran sel beta pankreas sehingga membran mengalami depolarisasi. Selanjutnya terjadi pembukaan kanal kalsium yang merangsang pemasukan kalsium ekstrasel ke dalam sel. Peningkatan kadar kalsium intrasel yang berlebihan dengan eliminasi yang terbatas mengakibatkan terjadinya gangguan homeostatis kalsium intrasel. Peningkatan kadar kalsium di dalam sel disertai dengan reaksi peroksidasi berlanjut oleh oksigen reaktif mengakibatkan kerusakan sel $\beta$-pankreas penghasil insulin yang merupakan pengendali kadar glukosa darah (Budavari, 1989; Halliwell, 1999; Halliwell et al., 1999). 
Sebanyak 25 ekor tikus dibuat hiperglikemik dengan diberikan suntikan aloksan tetrahidrat secara intravena pada dosis $130 \mathrm{mg} / \mathrm{kg}$ BB. Kemudian tikus dipelihara selama 5 hari hingga kondisi hiperglikemik tercapai. Semua tikus kemudian dipuasakan selama 16 jam. Selanjutnya dilakukan pengambilan darah melalui vena ekor dari masing-masing tikus, untuk kemudian diukur kadar glukosa darahnya (kadar glukosa darah awal) dan dipastikan bahwa semua tikus telah berada dalam kondisi hiperglikemik.

\section{Perlakuan terhadap hewan uji}

Nilai $\mathrm{LD}_{50}$-per oral ekstrak etanol $T$. decurrens telah diketahui dari penelitian Wikanta et al (2010) sebelumnya, yaitu sebesar $8,50 \mathrm{~g} / \mathrm{kg} \mathrm{BB}$. Untuk mengetahui efektifitas ekstrak $T$. decurrens dalam menurunkan kadar glukosa darah tikus hiperglikemik, maka sebanyak 30 ekor tikus ( 5 ekor tikus normal dan 25 ekor tikus hiperglikemik) dibagi menjadi 6 kelompok perlakuan. K-I (kontrol normal tanpa perlakuan), K-II (kontrol negatif, diberi air suling), K-III (diberikan ekstrak $T$. decurrens dosis rendah $0,85 \mathrm{~g} /$ hari/kg BB), K-IV (diberikan ekstrak $T$. decurrens dosis sedang 1,70 g/hari/kg BB), K-V (diberikan ekstrak $T$. decurrens dosis tinggi $3,40 \mathrm{~g} / \mathrm{hari} / \mathrm{kg} \mathrm{BB}$ ) serta K-VI (kontrol positif, diberikan obat antidiabetes glibenklamid dosis $0,90 \mathrm{mg} / \mathrm{hari} / \mathrm{kg} \mathrm{BB}$ ). Dosis glibenklamid untuk orang dewasa $10 \mathrm{mg} /$ hari, maka setelah dikalikan faktor konversi 0,018 untuk tikus, dosis menjadi sebesar $0,90 \mathrm{mg} / \mathrm{har} / \mathrm{kg}$ BB tikus (Katzung, 1989). Pemberian sediaan ekstrak uji dan kontrol positif glibenklamid dilakukan secara oral.

Semua tikus dipelihara dan diberi perlakuan selama 20 hari. Pada hari ke- $0,5,10,15$, dan 20 , terhitung sejak kondisi awal hiperglikemik, dilakukan pengambilan darah tikus dari semua kelompok perlakuan. Setiap kali pengambilan darah dilakukan, semua tikus terlebih dahulu dipuasakan selama 16 jam, kemudian ditimbang bobot badannya. Jumlah pakan dan minum yang tersisa juga dicatat sebagai data sekunder. Selanjutnya, dilakukan pengukuran kadar glukosa darah dengan metoda enzimatis (glukosa oksidase) menggunakan alat glukometer life scan (Anon., 1995).

Perubahan kadar glukosa darah yang terbentuk selama pengamatan berlangsung, dari setiap kelompok perlakuan, dibuat dalam bentuk grafik dan dihitung besarnya Luas Daerah Di Bawah Kurva/LDDK (Area Under the Curve/AUC). Potensi masing-masing dosis ekstrak $T$. decurrens dalam menurunkan kadar glukosa darah dihitung berdasarkan perbandingan antara persentase penurunan kadar glukosa darah dari masing-masing kelompok perlakuan dosis $T$. decurrens terhadap kontrol positif. Sedangkan persentase penurunan kadar glukosa darah dihitung berdasarkan perbandingan antara selisih LDDK kontrol negatif dengan kelompok perlakuan terhadap LDDK kontrol negatif dikali $100 \%$ berdasarkan rumus berikut (Ritschel, 1986):

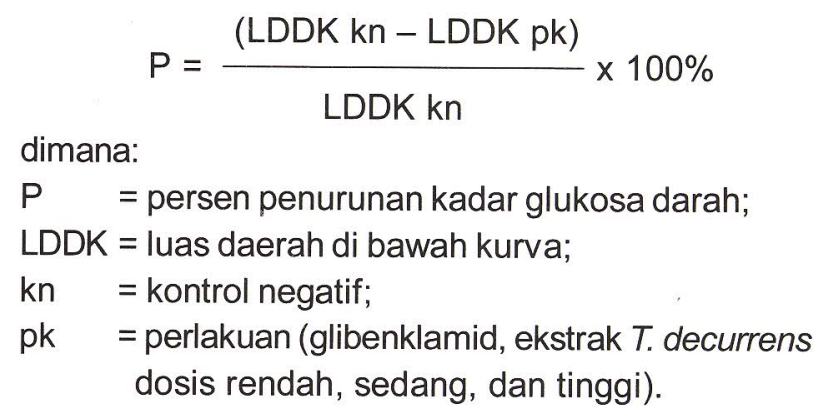

Setelah penelitian selesai, semua kelompok tikus dibedah dan diambil organ pankreasnya untuk dilakukan pemeriksaan histopatologi.

\section{Pembuatan sediaan histopatologi pankreas}

Untuk mengamati kondisi patologis yang terjadi pada organ pankreas dari setiap kelompok perlakuan maka dilakukan pengamatan secara mikroskopik terhadap pulau Langerhans dan sel- $\alpha$ pankreas menggunakan mikroskop cahaya dengan perbesaran 200x. Untuk keperluan tersebut maka dilakukan pembuatan preparat histologi meliputi tahap-tahap berikut: fiksasi, dehidrasi, penjernihan, infiltrasi, penanaman, penyayatan, penempelan, deparafinisasi, hidrasi, pewarnaan, dehidrasi, penjernihan, dan penutupan (Suntoro, 1983). Hasil pemeriksaan dibandingkan antara kelompok perlakuan terhadap kelompok kontrol positif dan kontrol negatif.

\section{Analisis Data}

Data-data hasil pengukuran dan pengamatan diuji normalitas dan homogenitasnya. Jika data normal dan homogen selanjutnya diuji dengan analisis statistik parametrik Anova satu arah. Jika hasil uji anova menunjukkan perbedaan bermakna, dilanjutkan dengan uji beda nyata terkecil (BNT) untuk melihat perbedaan antar kelompok perlakuan (Hanafiah, 1993).

\section{HASIL DAN BAHASAN}

\section{Kadar Glukosa Darah Tikus}

Rata-rata kadar glukosa darah tikus pada kondisi awal $(\mathrm{mg} / \mathrm{dL})$ untuk seluruh kelompok perlakuan berkisar antara $84,8-89 \mathrm{mg} / \mathrm{dL}$. Hasil analisis statistik menunjukkan bahwa kadar glukosa darah tikus pada kondisi awal bervariasi homogen dan terdistribusi normal. Hasil uji Anova menunjukkan bahwa tidak ada perbedaan bermakna antar kelompok perlakuan tikus pada kondisi awal atau kondisi normal tersebut. 
Setelah pemberian aloksan tetrahidrat (hari ke 0 perlakuan), rata-rata kadar glukosa darah tikus untuk $\mathrm{K}-\mathrm{II}, \mathrm{K}-\mathrm{III}, \mathrm{K}-\mathrm{IV}, \mathrm{K}-\mathrm{V}$, dan $\mathrm{K}-\mathrm{VI}$ mengalami kondisi hiperglikemik yaitu berkisar antara 327,2-349,4 mg/ dL. Ketentuan klinis menyatakan bahwa kondisi hiperglikemia atau diabetes dicapai bila kadar glukosa darah puasa $>100 \mathrm{mg} / \mathrm{dL}$ atau kadar glukosa darah sewaktu $>270 \mathrm{mg} / \mathrm{dL}$ (Tjokroprawiro, 1999). Hasil uji yang pada awal kondisi hiperglikemik memiliki kadar glukosa darah $343,2 \mathrm{mg} / \mathrm{dL}$, hingga akhir pengamatan mengalami penurunan menjadi $106,2 \mathrm{mg} / \mathrm{dL}$. K-IV (dosis sedang) yang pada awal kondisi hiperglikemik memiliki kadar glukosa darah $327,2 \mathrm{mg} / \mathrm{dL}$, hingga akhir pengamatan mengalami penurunan menjadi $175,2 \mathrm{mg} / \mathrm{dL}$. K-V (dosis tinggi) pada awal kondisi hiperglikemik memiliki kadar glukosa darah $333 \mathrm{mg} /$
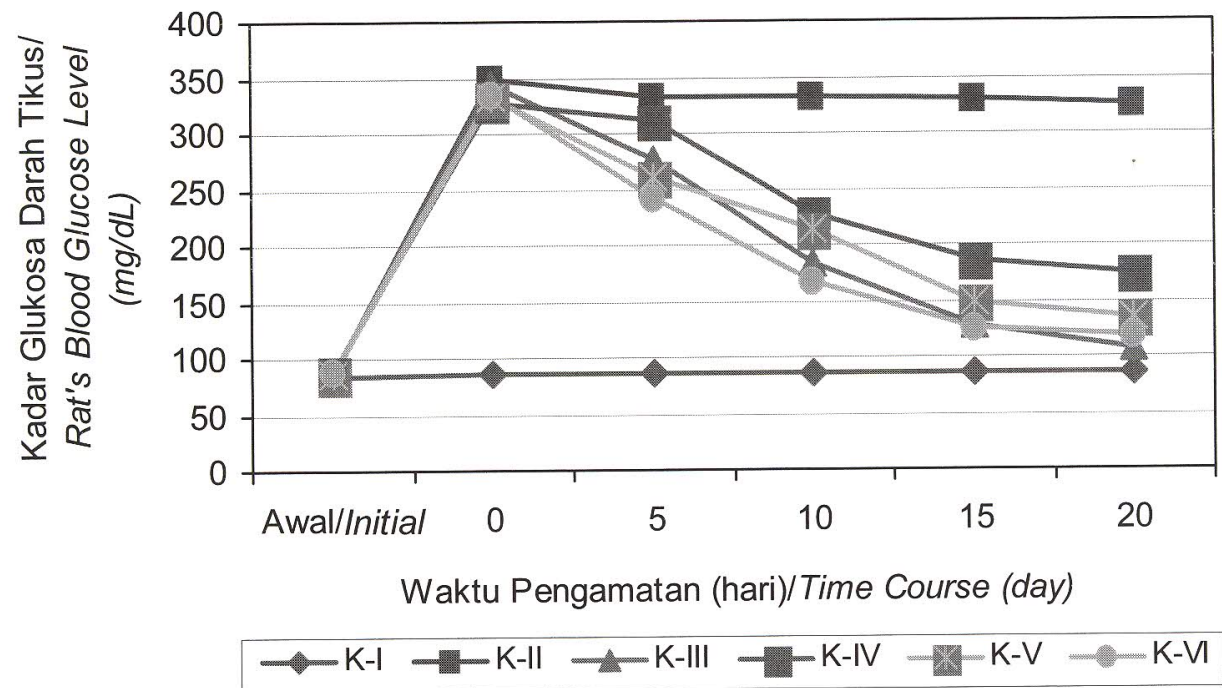

Keterangan/Note:

$\mathrm{K}-\mathrm{I}=\mathrm{kontrol}$ normal/normal control;

$\mathrm{K}-\mathrm{II}=$ kontrol negatif/negative control;

$\mathrm{K}-\mathrm{III}=$ ekstrak $T$. decurrens dosis rendah/ $\mathrm{T}$. decurrens extract low dose;

$\mathrm{K}-\mathrm{IV}=$ ekstrak $T$. decurrens dosis sedang/T. decurrens extract medium dose;

$\mathrm{K}-\mathrm{V}=$ ekstrak $T$. decurrens dosis tinggi/ $T$. decurrens extract high dose;

$\mathrm{K}-\mathrm{VI}=$ kontrol positif (glibenklamid)/Positive control (glibenclamide)

Gambar 1. Rata-rata kadar glukosa darah tikus ( $\mathrm{mg} / \mathrm{dL}$ ) selama percobaan. Figure 1. Mean of rat's blood glucose level $(\mathrm{mg} / \mathrm{dL})$ during experiment.

Anova menunjukkan bahwa tidak ada perbedaan bermakna antar kelompok perlakuan pada tikus yang mengalami kondisi hiperglikemik. Rata-rata kadar glukosa darah tikus dari setiap kelompok perlakuan selama penelitian disajikan pada Gambar 1.

Dapat dilihat bahwa kadar glukosa darah tikus pada kondisi awal (normal) berkisar antara 84,8-87,4 mg/ $\mathrm{dL}$, langsung meningkat pesat ke kondisi hiperglikemia atau diabetes menjadi $327,2-349,4 \mathrm{mg} / \mathrm{dL}$ (hari ke0 ), kecuali untuk kontrol normal $(K-I)$ yang relatif konstan selama pengamatan berlangsung, yaitu berkisar antara 85,2-86,4 mg/dL. K-II (kontrol negatif) yang pada awal kondisi hiperglikemik memiliki kadar glukosa darah $349,4 \mathrm{mg} / \mathrm{dL}$, hingga akhir pengamatan hanya mengalami sedikit penurunan menjadi 326,6 $\mathrm{mg} / \mathrm{dL}$. Sementara itu, pemberian perlakuan ekstrak T. decurrens (K-III, K-IV, dan K-V) dan perlakuan obat antidiabet (K-VI) mampu menurunkan kadar glukosa darah tikus. K-III (kelompok perlakuan dosis rendah)
$\mathrm{dL}$, hingga akhir pengamatan mengalami penurunan menjadi 134,2 mg/dL. Sedangkan K-VI (kontrol positif) dari kondisi hiperglikemik dengan kadar glukosa darah sekitar $334 \mathrm{mg} / \mathrm{dL}$, hingga akhir pengamatan turun menjadi sekitar $118,6 \mathrm{mg} / \mathrm{dL}$.

Secara jelas dapat dilihat bahwa pemberian ekstrak etanol $T$. decurrens dengan dosis rendah, sedang, dan tinggi dapat membantu penurunan kadar glukosa tikus. Untuk mengetahui secara kuantitatif potensi suatu bahan aktif dalam menurunkan kadar glukosa darah maka dilakukan perhitungan LDDK perubahan kadar glukosa darah selama percobaan berlangsung.

\section{Luas Daerah di Bawah Kurva (LDDK)}

Untuk mengetahui potensi masing-masing dosis bahan aktif dalam menurunkan kadar glukosa darah maka dilakukan perhitungan LDDK kadar glukosa darah tikus dari setiap kelompok perlakuan selama 


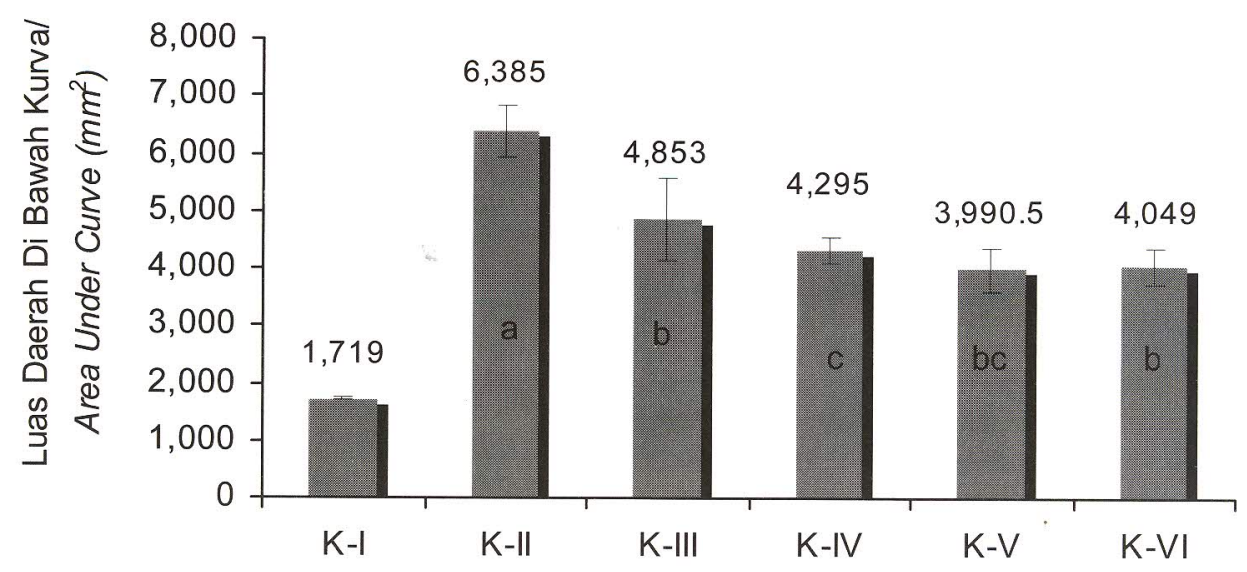

Kelompok Perlakuan/Group of Treatment

Keterangan/Note: berbeda notasi berarti berbeda nyata/different notation means significantly different

$\mathrm{K}-\mathrm{I}=\mathrm{kontrol}$ normal/normal control;

$\mathrm{K}-\mathrm{II}=\mathrm{kontrol}$ negatif/negative control;

$\mathrm{K}-\mathrm{III}=$ ekstrak $T$. decurrens dosis rendah/T. decurrens extract low dose;

$\mathrm{K}-\mathrm{IV}=$ ekstrak $T$. decurrens dosis sedang/T. decurrens extract medium dose;

$\mathrm{K}-\mathrm{V}=$ ekstrak $T$. decurrens dosis tinggi/T. decurrens extract high dose;

$\mathrm{K}-\mathrm{VI}=$ kontrol positif (glibenklamid)/Positive control (glibenclamide)

Gambar 2. Rata-rata luas daerah di bawah kurva $\left(\mathrm{mm}^{2}\right)$ kadar glukosa darah tikus selama percobaan.

Figure 2. Mean of area under curve of rat's blood glucose level $\left(\mathrm{mm}^{2}\right)$ during experiment.

percobaan berlangsung (Ritschel, 1986) dibandingkan terhadap kelompok kontrol. Hasil perhitungan nilai LDDK dari masing-masing perlakuan disajikan pada Gambar 2.

Besarnya nilai LDDK untuk K-I (kontrol normal), K-II (kontrol negatif), K-III (dosis rendah), K-IV (dosis sedang), K-V (dosis tinggi), dan K-VI (kontrol positif) masing-masing adalah 1,$719 ; 6,385 ; 4,853 ; 4,285$; 3,990.5; dan 4,049 $\mathrm{mm}^{2}$. Hasil analisis statistik anova dan uji beda nyata terkecil menunjukkan bahwa semua kelompok perlakuan (K-III, K-IV, K-V, dan KVI (kontrol positif)) dibandingkan dengan K-II (kontrol negatif) menunjukkan efek menurunkan kadar glukosa darah secara nyata.

Nilai LDDK K-III tertinggi di antara tiga dosis $T$. decurrens yang diujikan yang mengindikasikan bahwa $\mathrm{K}$-III (dosis rendah) memiliki kemampuan terendah dalam menurunkan kadar glukosa darah tikus hiperglikemia. Sementara itu, analisis statistik menunjukkan bahwa nilai LDDK perlakuan dosis sedang (K-IV) dan dosis tinggi (K-V) tidak berbeda nyata dengan dengan perlakuan obat antidiabetes glibenklamid (K-VI). Hal ini menunjukkan bahwa perlakuan $\mathrm{K}-\mathrm{IV}$ dan $\mathrm{K}-\mathrm{V}$ mempunyai kemampuan setara dengan obat antidiabetes glibenkamid untuk menurunkan kadar glukosa darah tikus hiperglikemia.

Hasil perhitungan potensi ekstrak $T$. decurrens dalam menurunkan kadar glukosa darah disajikan pada Gambar 3. Berdasarkan hasil yang diperoleh dapat diketahui bahwa semakin tinggi dosis sediaan ekstrak $T$. decurrens yang diberikan pada tikus hiperglikemik secara linier meningkatkan kemampuan ekstrak untuk menurunkan kadar glukosa darah hiperglikemik. Pemberian ekstrak dosis tinggi (K-V) yaitu dosis $3,40 \mathrm{~g} / \mathrm{hari} / \mathrm{kg}$ BB menghasilkan penurunan kadar glukosa darah tertinggi dibandingkan perlakuan lain, bahkan lebih tinggi dibandingkan kontrol positif (K-VI) yang diberikan obat anti-diabetes glibenkamid dengan dosis $0,90 \mathrm{mg} / \mathrm{har} / \mathrm{kg}$ BB.

\section{Rata-rata Bobot Badan Tikus Sebelum dan Sesudah Perlakuan}

Kondisi hiperglikemia merupakan salah satu kondisi kelainan metabolisme dengan gejala khas terjadinya penurunan bobot badan, padahal nafsu makannya tetap baik. Pemberian aloksan tetrahidrat terhadap hewan uji menyebabkan kerusakan sel $\beta$ pankreas penghasil insulin, yang kemudian mengakibatkan menurunnya produksi insulin dalam tubuh. Keadaan tersebut mengakibatkan ketidakmampuan tubuh untuk mengendalikan kadar glukosa darah. Sebagian besar glukosa darah tidak dapat dimetabolisme atau dikonversi menjadi energi. Karena hasil metabolisme glukosa tidak mencukupi kebutuhan energi dalam tubuh, maka untuk memenuhi kebutuhan energi tubuh tersebut cadangan lemak dan protein tubuh dikonversi menjadi energi secara terus 


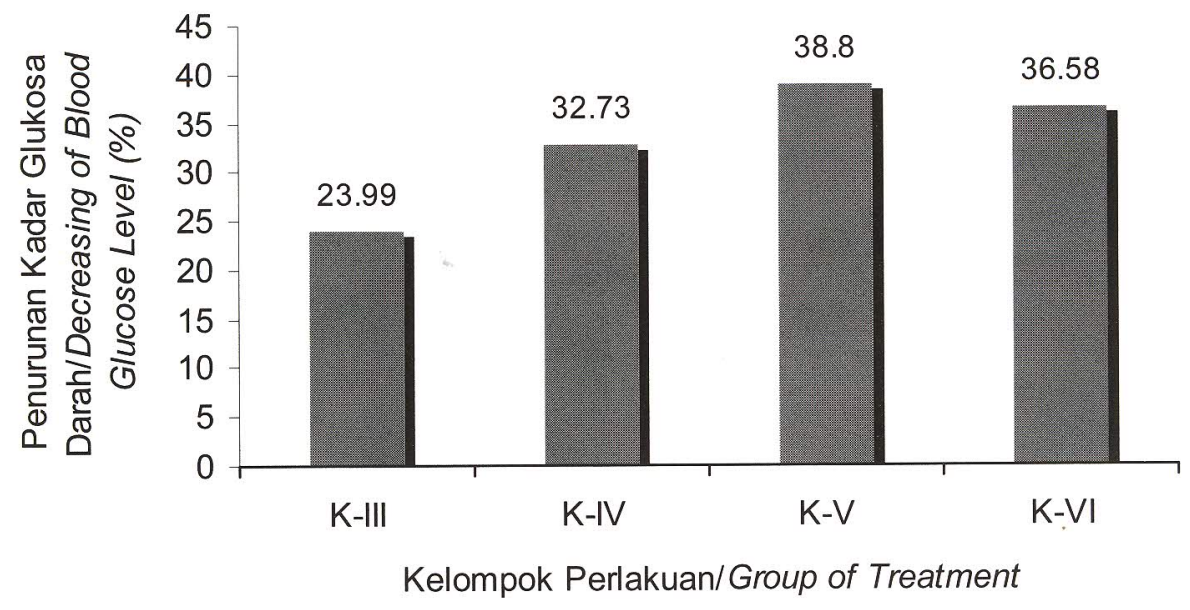

Keterangan/Note:

$\mathrm{K}-\mathrm{III}=$ ekstrak $T$. decurrens dosis rendah/T. decurrens extract low dose;

$\mathrm{K}-\mathrm{IV}=$ ekstrak $T$. decurrens dosis sedang/T. decurrens extract medium dose;

$\mathrm{K}-\mathrm{V}=$ ekstrak $T$. decurrens dosis tinggi/T. decurrens extract high dose;

$\mathrm{K}-\mathrm{VI}=$ kontrol positif (glibenklamid)/Positive control (glibenclamide)

Gambar 3. Potensi penurunan kadar glukosa darah tikus oleh masing-masing kelompok ekstrak T. decurrens $\mathrm{K}-\mathrm{III}, \mathrm{K}-\mathrm{IV}$, dan K-V dibandingkan terhadap kontrol positif glibenklamid K-VI.

Figure 3. Decreasing potency on rat's blood glucose level by T. decurrens extract of K-III, K-IV and K-V compared to positive control glibenclamide.

menerus. Akibatnya, bobot tubuh makin lama makin menurun (Tjokroprawiro, 1999; Widowati, 2003).

Hasil penimbangan rata-rata bobot badan tikus dari masing-masing kelompok percobaan $\mathrm{K}-\mathrm{I}, \mathrm{K}-\mathrm{II}, \mathrm{K}-\mathrm{III}$,
K-IV, K-V, dan K-VI, pada hari ke-0, 5, 10, 15, dan 20 selama percobaan berlangsung disajikan pada Gambar 4. Selama penelitian berlangsung kelompok I mengalami peningkatan bobot badan dari $175,80 \mathrm{~g}$

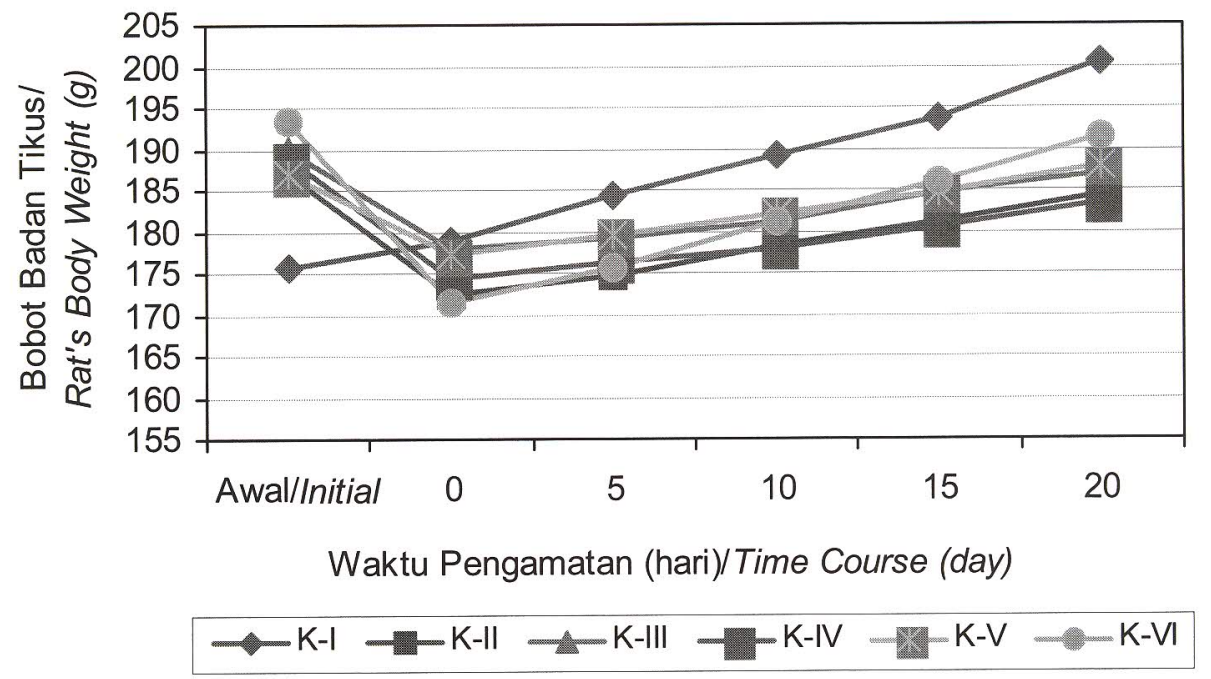

Keterangan/Note:

$\mathrm{K}-\mathrm{I}=$ kontrol normal/normal control;

$\mathrm{K}-\mathrm{II}=\mathrm{kontrol}$ negatif/negative control;

$\mathrm{K}$-III = ekstrak $T$. decurrens dosis rendah/T. decurrens extract low dose;

$\mathrm{K}-\mathrm{IV}=$ ekstrak $T$. decurrens dosis sedang/T. decurrens extract medium dose;

$\mathrm{K}-\mathrm{V}=$ ekstrak $T$. decurrens dosis tinggi/T. decurrens extract high dose;

$\mathrm{K}-\mathrm{VI}=$ kontrol positif (glibenklamid)/Positive control (glibenclamide)

Gambar 4. Rata-rata bobot badan tikus selama percobaan.

Figure 4. Mean of rat's body weight during experiment. 
menjadi 196,6 g. Pada hari ke-0, lima hari setelah penyuntikan aloksan, K-II, K-III, K-IV, K-V, dan K-VI mengalami kondisi hiperglikemia sehingga mengalami penurunan bobot badan dari sekitar 186,8-193,4 g menjadi sekitar 171,4-177,8 g. Selanjutnya, tikus mengalami peningkatan bobot badan menjadi sekitar 183,4-191,4 g pada hari ke-20. Namun demikian, peningkatan bobot badan tersebut belum dapat mencapai kondisi normal (kondisi awal sebelum perlakuan). Hal tersebut dikarenakan proses perbaikan berlangsung secara bertahap setelah mengkonsumsi ekstrak $T$. decurrens dan obat anti-diabetes glibenklamid. Pada K-II (kontrol negatif), bobot badan juga mengalami perbaikan secara lamban bertahap yang disebabkan konsumsi pakan yang baik.

\section{Kebutuhan Pakan dan Volume Air Minum Tikus}

Kondisi hiperglikemia yang ditandai dengan kadar glukosa darah yang sangat tinggi mengakibatkan glukosa dalam ginjal melampaui nilai ambang. Untuk menurunkan kadar glukosa dalam ginjal, maka glukosa dikeluarkan melalui urin (disebut glukosuria). Akibatnya, penderita diabetes sering mengalami kondisi diuresis (banyak keluar air seni) dan dehidrasi sehingga selalu merasa haus. Walaupun terjadi peningkatan masukan air minum, dan banyak makan tetapi bobot badan menurun (Tjokroprawiro, 1999; Dalimartha, 2002).
Bobot pakan tikus yang dikonsumsi selama percobaan berlangsung disajikan pada Gambar 5 .

Tampak bahwa bobot pakan yang dibutuhkan tikus kelompok kontrol normal relatif konstan selama penelitian berlangsung, yaitu berkisar antara 13,4614,12 g. Sementara itu, jika dibandingkan dengan KI, kelompok perlakuan yang lain K-II, K-III, K-IV, K-V, dan $\mathrm{K}-\mathrm{VI}$ pada hari ke-0, mengalami peningkatan kebutuhan jumlah pakan. Hal tersebut menjadi indikasi bahwa pada hari ke-0, K-II, K-III, K-IV, K-V, dan K-VI telah mengalami kondisi hiperglikemia atau diabetes yaitu dengan bobot badan rendah tetapi kebutuhan pakan tinggi (polifagia). Pada hari selanjutnya terlihat kebutuhan pakan tikus K-III, K-IV, K-V, dan K-VI makin menurun menuju ke kondisi awal seperti pada K-I. Kondisi tersebut terjadi setelah pemberian perlakuan ekstrak $T$. decurrens (K-III, K-IV, dan K-V) dan perlakuan obat antidiabetes $(\mathrm{K}-\mathrm{V} \mathrm{l})$. Sedangkan pada kontrol negatif (K-II), tikus tetap mengalami kondisi hiperglikemia sampai akhir masa percobaan yang ditandai dengan kebutuhan jumlah pakan yang makin meningkat terus.

Volume air minum yang dibutuhkan tikus selama percobaan berlangsung disajikan pada Gambar 6 . Terlihat bahwa K-II, K-III, K-IV, K-V, dan K-VI yang mengalami kondisi hiperglikemia atau diabetes memerlukan jumlah air minum yang lebih banyak (polidipsia) dibandingkan $\mathrm{K}-\mathrm{I}$ yang tidak mengalami kondisi hiperglikemia atau diabetes (kontrol normal).

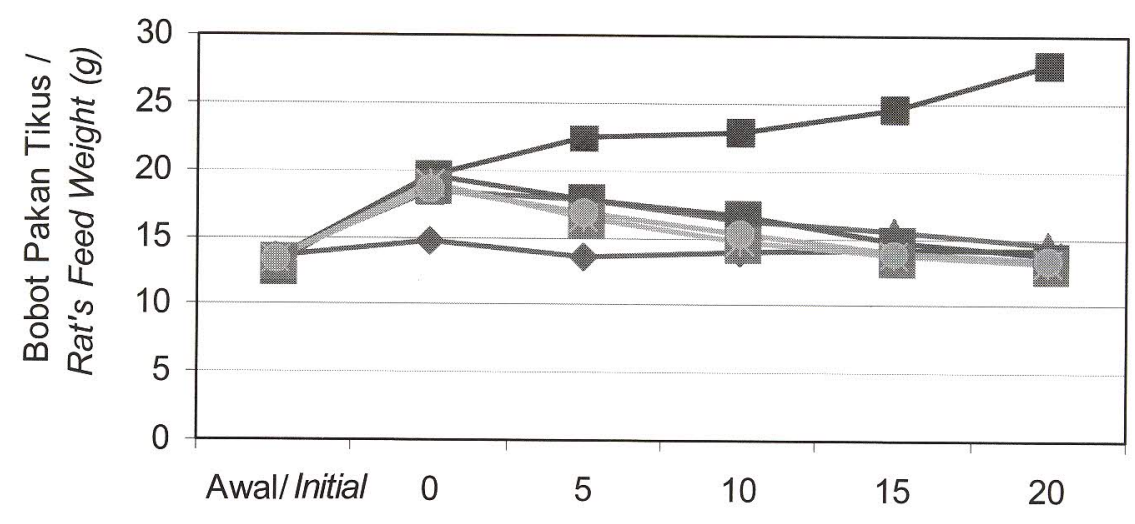

Waktu Pengamatan (hari)/Time Course (day)

Keterangan/Note:

$\mathrm{K}-\mathrm{I}=\mathrm{kontrol}$ normal/normal control;

$\mathrm{K}-\mathrm{II}=\mathrm{kontrol}$ negatif/negative control;

$\mathrm{K}-\mathrm{III}=$ ekstrak $T$. decurrens dosis rendah/T. decurrens extract low dose;

$\mathrm{K}-\mathrm{IV}=$ ekstrak $T$. decurrens dosis sedang/T. decurrens extract medium dose;

$\mathrm{K}-\mathrm{V}=$ ekstrak $T$. decurrens dosis tinggi/T. decurrens extract high dose;

$\mathrm{K}-\mathrm{VI}=$ kontrol positif (glibenklamid)/Positive control (glibenclamide)

Gambar 5. Rata-rata bobot pakan tikus selama percobaan. Figure 5. Mean of rat's feed weight during experiment. 


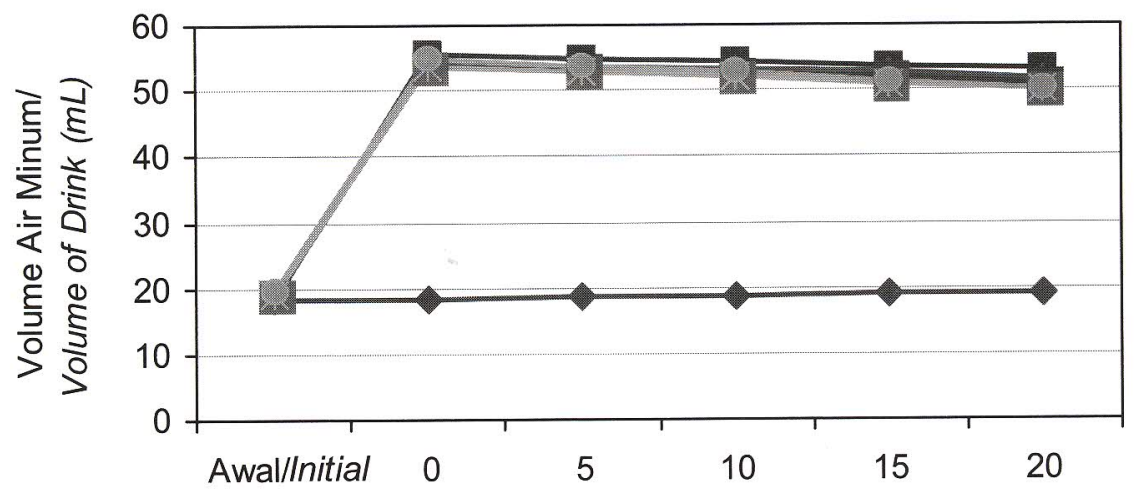

Waktu Pengamatan (hari)/Time Course (day)

$\rightarrow \mathrm{K}-\mathrm{I} \rightarrow \mathrm{K}-\mathrm{II} \rightarrow \mathrm{K}-\mathrm{III}-\mathrm{K}-\mathrm{IV} \rightarrow \mathrm{E}-\mathrm{K}-\mathrm{V} \rightarrow \mathrm{K}-\mathrm{VI}$

Keterangan/Note:

$\mathrm{K}-\mathrm{I}=$ kontrol normal/normal control;

$\mathrm{K}-\mathrm{II}=\mathrm{kontrol}$ negatif/negative control;

$\mathrm{K}-\mathrm{III}=$ ekstrak $T$. decurrens dosis rendah/T. decurrens extract low dose;

$\mathrm{K}-\mathrm{IV}=$ ekstrak $T$. decurrens dosis sedang/T. decurrens extract medium dose;

$\mathrm{K}-\mathrm{V}=$ ekstrak $T$. decurrens dosis tinggi/T. decurrens extract high dose;

$\mathrm{K}-\mathrm{VI}=$ kontrol positif (glibenklamid)/Positive control (glibenclamide)

Gambar 6. Rata-rata volume air minum tikus selama percobaan.

Figure 6. Mean of rat's drink water volume during experiment.

\section{Analisis Histopatologi Pankreas Tikus Hiperglikemik}

Untuk mengamati kondisi patologis pada organ pankreas akibat pemberian aloksan dan efek pemberian esktrak $T$. decurrens dari setiap kelompok perlakuan dosis dan pemberian obat antidiabet glibenklamid maka dilakukan pengamatan secara mikroskopik terhadap pulau Langerhans dan sel $\beta$ pankreas menggunakan mikroskop cahaya dengan perbesaran $10 \times 20$ (Suntoro, 1983) dengan hasil sebagai berikut.

\section{Diameter Rata-rata Pulau Langerhans}

Untuk mengetahui kondisi pulau Langerhans tikus yang diinduksi aloksan tetrahidrat maka dilakukan pengukuran diameter pulau Langerhans pada semua tikus. Hasil pengukuran diameter pulau Langerhans disajikan pada Gambar 7.

Dapat dilihat bahwa nilai rata-rata diameter pulau Langerhans pada K-II (kontrol negatif) 98,36 um jauh lebih kecil daripada K-I (kontrol normal) 129,57 $\mu \mathrm{m}$, yang mengindikasikan bahwa induksi aloksan tetrahidrat pada tikus menyebabkan kerusakan pulau Langerhans organ pankreasnya. Sedangkan diameter pulau Langerhans pada K-III (116.83 $\mu \mathrm{m}), \mathrm{K}-\mathrm{IV}$ (120.32 $\mu \mathrm{m}), \mathrm{K}-\mathrm{V}(123.44 \mu \mathrm{m})$, dan K-VI $(123,71 \mu \mathrm{m})$ lebih besar daripada K-II $(98,36 \mu \mathrm{m})$. Hal ini menunjukkan bahwa pemberian ekstrak T. decurrens (K-III, K-IV, dan $\mathrm{K}-\mathrm{V}$ ) dan obat antidiabet glibenklamid dapat membantu proses perbaikan organ pankreas yang rusak karena induksi aloksan.

Sejalan dengan hasil pengukuran kadar glukosa darah (Gambar 1), LDDK (gambar 2), dan potensi penurunan kadar glukosa darah (Gambar 3) sebelumnya, hasil pengukuran rata-rata diameter pulau Langerhans memperlihatkan bahwa semakin tinggi pemberian dosis ekstrak T. decurrens ternyata secara linier dapat memberikan peningkatan efek perbaikan pankreas, yang ditandai dengan peningkatan ukuran diameter pulau Langerhans. Pemberian ekstrak T. decurrens dosis 3,40 g/hari/kg $\mathrm{BB}(\mathrm{K}-\mathrm{V})$ mampu memberikan efek perbaikan pankreas yang tidak berbeda dengan kontrol positif $\mathrm{K}-\mathrm{VI}$ (glibenkamid dosis 0,90 mg/hari/kg BB). Di lain pihak, walaupun efek perbaikan kerusakan pankreas perlakuan K-III dan K-IV masih lebih kecil dibandingkan perlakuan K-V dan kontrol positif K-VI, namun kedua perlakuan tersebut secara signifikan mampu memperbaiki kerusakan pankreas dibandingkan dengan kontrol negatif (K-II).

\section{Jumlah Sel $\beta$-pankreas dalam Pulau Langerhans}

Untuk mengetahui efek induksi aloksan terhadap fungsi pankreas, maka dilakukan penghitungan jumlah 


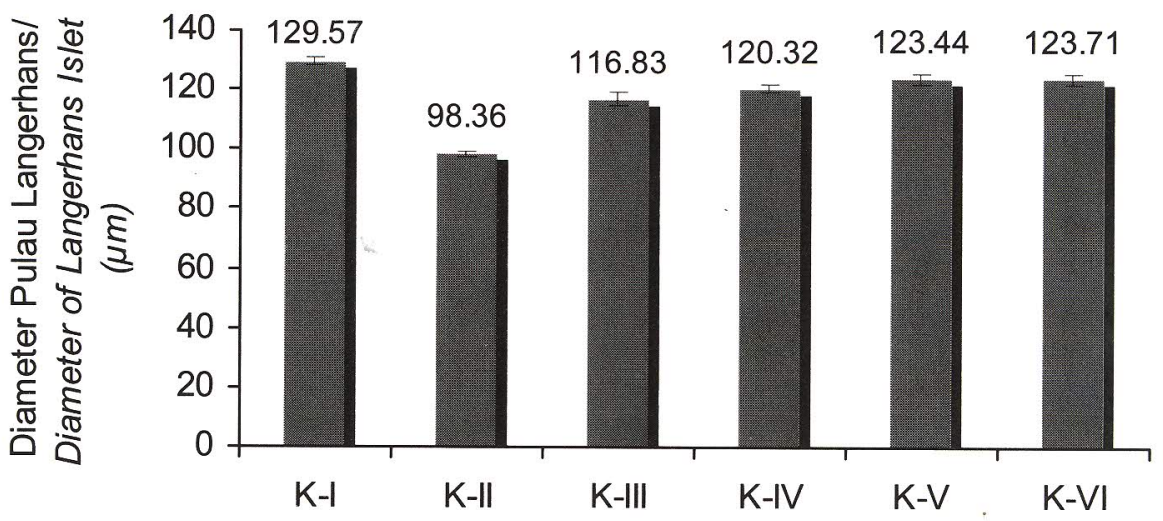

Kelompok Perlakuan/Group of Treatment

Keterangan/Note: berbeda notasi berarti berbeda nyata/different notation means significantly different

$\mathrm{K}-\mathrm{I}=$ kontrol normal/normal control;

$\mathrm{K}-\mathrm{II}=\mathrm{kontrol}$ negatif/negative control;

$\mathrm{K}-\mathrm{III}=$ ekstrak $T$. decurrens dosis rendah/T. decurrens extract low dose;

$\mathrm{K}-\mathrm{IV}=$ ekstrak $T$. decurrens dosis sedang/T. decurrens extract medium dose;

$\mathrm{K}-\mathrm{V}=$ ekstrak $T$. decurrens dosis tinggi/T. decurrens extract high dose;

$\mathrm{K}-\mathrm{VI}=$ kontrol positif (glibenklamid)/Positive control (glibenclamide)

Gambar 7. Rata-rata diameter pulau Langerhans.

Figure 7. Mean diameter of Langerhans islet.

sel- $\beta$ pankreas dalam pulau Langerhans pada semua tikus uji. Hasil perhitungan disajikan pada Gambar 8.

Dapat dilihat bahwa jumlah sel- $\beta$ pankreas pada K-I (kontrol normal) sebanyak 29 buah, sedangkan pada K-II (kontrol negatif) sangat sedikit, yaitu sekitar 7,8 buah yang dikarenakan sel- $\beta$ pankreas mengalami kerusakan akibat induksi aloksan. Jumlah sel- $\beta$ pada K-III (13,2 buah), K-IV (18,2 buah), dan K-V (25 buah),

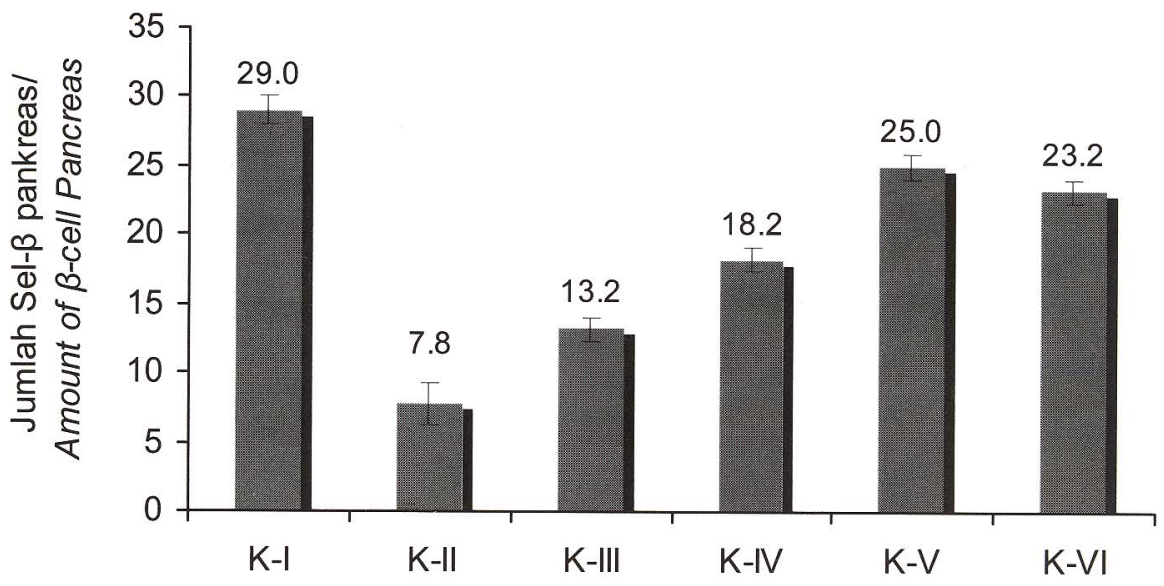

Kelompok Perlakuan/Group of Treatment

Keterangan/Note: berbeda notasi berarti berbeda nyata/different notation means significantly different

$\mathrm{K}-\mathrm{I}=\mathrm{kontrol}$ normal/normal control;

$\mathrm{K}-\mathrm{II}=\mathrm{kontrol}$ negatif/negative control;

$\mathrm{K}$-III = ekstrak $T$. decurrens dosis rendah/T. decurrens extract low dose;

$\mathrm{K}-\mathrm{IV}=$ ekstrak $T$. decurrens dosis sedang/T. decurrens extract medium dose;

$\mathrm{K}-\mathrm{V}=$ ekstrak $T$. decurrens dosis tinggi/T. decurrens extract high dose;

$\mathrm{K}-\mathrm{VI}=$ kontrol positif (glibenklamid)/Positive control (glibenclamide)

Gambar 8. Jumlah sel $\beta$-pankreas dalam pulau Langerhans.

Figure 8. Number of $\beta$-pancreas cell in Langerhans islet. 
dan K-VI ( 23,2 buah), jauh lebih banyak dari pada KII. Hal ini menunjukkan bahwa pemberian ekstrak $T$. decurrens dapat membantu proses perbaikan sel- $\beta$ pankreas yang mengalami kerusakan akibat induksi aloksan. Perbaikan tersebut bersifat meningkat linier sejalan dengan meningkatnya dosis ekstrak yang diberikan. Pemberian ekstrak $T$. decurrens dosis 3,40 $\mathrm{g} / \mathrm{hari} / \mathrm{kg}$ BB (K-V) memberikan efek perbaikan sel- $\beta$ pankreas yang lebih baik dibandingkan dengan kontrol positif K-VI (glibenkamid dosis $0,90 \mathrm{mg} / \mathrm{hari} / \mathrm{kg} \mathrm{BB}$ ).

\section{KESIMPULAN}

Pemberian ekstrak etanol $T$. decurrens dosis 0,85 $\mathrm{g} / \mathrm{hari} / \mathrm{kg} \mathrm{BB}$, dosis $1,70 \mathrm{~g} / \mathrm{hari} / \mathrm{kg} \mathrm{BB}$, dan dosis 3,40 $\mathrm{g} / \mathrm{hari} / \mathrm{kg}$ BB mampu menurunkan kadar glukosa darah tikus yang mengalami kondisi hiperglikemia, dan mampu membantu proses perbaikan organ pankreas yang mengalami kerusakan akibat induksi aloksan tetrahidrat. Pemberian ekstrak etanol $T$. decurrens dosis $3,40 \mathrm{~g} / \mathrm{hari} / \mathrm{kg} \mathrm{BB}$ memberikan efek yang lebih baik dibandingkan obat anti-diabetes glibenkamid dosis $0,90 \mathrm{mg} / \mathrm{hari} / \mathrm{kg}$ BB dalam menurunkan kadar glukosa darah tikus yang mengalami kondisi hiperglikemia dan dalam memperbaiki organ pankreas yang rusak oleh induksi aloksan tetrahidrat.

\section{DAFTAR PUSTAKA}

Anonymous. 1995. Brosur Life Scan Sure Step. Johnson and Johnson Co., Milpitas, USA. 2 pp.

Budavari. 1989. The Merck Index. 11 th ed. New York: Published by Merck Co. Inc. Rahway. 279 pp.

Dalimartha, S. 2002. Ramuan Tradisional untuk Pengobatan Diabetes Mellitus. Penebar Swadaya, Jakarta. $28 \mathrm{pp}$.

Djilani, A., Toudert, N., and Djilani, S. 2011. Evaluation of the hypoglycemic effect and antioxidant activity of methanol extract of Ampelodesma mauritanica roots.
Life Science and Medicine Research. LSMR-31. p. $1-6$.

Halliwell, B. 1999. Free radicals in biology and medicine, ed. 4. Oxford University Press. p. 561-563.

Halliwell, B., John, M. C., and Gutteridge, J.M.C. 1999. Free Radicals in Biology and Medicine. 3th edition. Oxford University Press, New York. p. 411-555.

Hanafiah, A. 1993. Rancangan Percobaan: Teori dan Aplikasi. Fakultas Pertanian Universitas Sriwijaya, Palembang. 57 pp.

KKI Phytomedica. 1993. Kelompok Kerja IImiah Phytomedica; Penapisan Farmakologi, Pengujian Fitokimnia, dan Pengujian Klinik. Yayasan Pengembangan Obat Alam Phytomedica, Jakarta. p. 16-17.

Katzung, B.G. 1989. Farmakologi Dasar dan Klinik. Edisi 3. Alih bahasa: Binawati Hk. EGC, Jakarta. p. 577591.

Ritschel, W.A. 1986. Handbook of Basic Pharmacokinetics, 3ed. Drug Intelligence Publications, Inc., Hamilton, USA. p. 269-291.

Suntoro, S.H. 1983. Metode Pewarnaan Histopatologi dan Histokimia. Phratara Karya Aksara, Jakarta. p. 72-79.

Szkudelski, T. 2001. The mechanism of alloxan and streptozotocin action in beta cell of rat pancreas. Physiol Res. March. p. 536-546.

Tjokroprawiro, A. 1999. Diabetes Mellitus, Klasifikasi, Diagnosis dan Terapi. Edisi 3. Gramedia, Jakarta. p. $1-16$.

Widowati, L. 2003. Pengaruh Ekstrak Biji Trigonella Foenum-graecum L. terhadap Kadar Gula Darah, Glutation, dan Gambaran Kerusakan Sel Beta Pankreas pada Tikus NIDDM. Program Studi IImu Kefarmasian, Universitas Indonesia, Jakarta. p. 20 73.

Wikanta, T., Prehati, R., Rahayu, L., dan Fajarningsih, N.D. 2010. Pengaruh pemberian ekstrak etanol Turbinaria decurrens terhadap perbaikan kerusakan hati tikus putih. Jurnal Pascapanen dan Bioteknologi Kelautan dan Perikanan. 5(1): 19-28 